\title{
An Overview of Factors Affecting Auditing Quality in Albania
}

\author{
Marsel Sulanjaku \\ Phd. Lecturer in Finance \& Accounting Department. Faculty of Economics, University of Elbasan \\ "5 Maji", Pall. Nr 730, H2/4, Elbasan (3001), Elbasan (3001) Albania \\ E-mail: marsel.sulanjaku@uniel.edu.al \\ Ali Shingjergji \\ Phd. Lecturer in Finance \& Accounting Department. Faculty of Economics, University A.Xhuvani \\ Pall. Nr 20, H3/2, Elbasan (3001), Elbasan (3001) Albania \\ E-mail: ali.shingjergji@uniel.edu.al
}

\section{Doi:10.5901/ajis.2015.v4n3s1p223}

\section{Abstract}

The effects of the financial crisis during the last decade derived by major financial scandals in major corporations and the uncertainty that still follows the economic situation has emphasized the need to regain the confidence of the users in the financial information. In these conditions, the need for certified and reliable financial information is a challenge that mostly affects the auditors, which should be stimulated to improve the audit quality. There is a wide range of studies and authors who try to determine the most influence factors that affects the auditing quality. The objective of this paper is to study how various internal and external factors like audit firm culture, quality of people, management and audit committee as well as general cultural and political factors affects the audit quality in Albania. Identifying the main factors that can improve the auditing quality in Albania can contribute to our understanding of how the Albanian auditors adopt the auditing standards to accomplish the quality control and other related reporting responsibilities. The study will be widely based on international standards on auditing and assurance engagements to identify the main factors affecting the quality control of auditing according to most popular and used classification. The objective of this study will be completed by analyzing the views from the respondents (CPA and independent auditors) obtained from the utilization of the questionnaires and interviews as well as the usage of foreign and national literature.

Keywords: auditing quality, internal factors, auditing standard, CPA.

\section{Introduction}

Auditing is a concept that emerged when the first formal record-keeping systems were first instituted by organized business and governments in the Near East to allay their concerns about correctly accounting for receipts and disbursements and collecting taxes. ${ }^{1}$ Today's audit involves performing procedures to obtain evidence about amounts and disclosures in the financial statements so as to evaluate the appropriateness of accounting estimates made by management (KPMG, 2008). Financial reporting scandals in major corporations like Enron, Sunbean, Worldcom etc. has shown how fragile our modern economy is and what consequences can cause a non effective performed auditing tasks. The necessity of auditing is becoming more evident in today's modern economy where a large number of persons are depending on reliable financial information in order to invest in companies listed in international stock markets. The complexity of today's economic transactions, the separation in geographic aspect, time and expertise, between stakeholders, managers and potential investors has made the auditors and auditing process a necessity for the continuity of the modern economic system. Some of the more important auditing procedures include2: Inquiring of management and others to gain an understanding of the organization itself, its operations, financial reporting, and known fraud or error; evaluating and understanding the internal control system; performing analytical procedures on expected or unexpected variances in account balances or classes of transactions; testing documentation supporting account balances or classes

\footnotetext{
1 Sridhar Ramamoorti (2003), internal auditing: history, evolution, and prospects. IIARF publishing.

2 http://www.grfcpa.com/media/AuditorDoesandDoesntDo_Final.pdf
} 
of transactions; observing the physical inventory count; confirming accounts receivable and other important accounts with a third party

Auditing is a process of certifying the financial information weather they represent a fair view of economical transactions. Auditing adds credibility to the financial information by providing an opinion regarding the correctness of the financial report provided by the economic entities. The more credible the financial statement can be the more the potential investors can invest in companies and the more is economic growth expected to be. The audit quality plays an important role in the usage of the financial statements by the potential investors as well as the users of this financial information. Quality of auditing is a wide concept and intangible from its matter because it cannot be measured in a quantitative manner nor it can be concluded objectively in a qualitative manner. Many authors describe and define the auditing quality from different aspects. Some authors define it as the capability of an auditor to find and report material errors, misrepresentation and weather the financial statements are based on international accounting standards. These factors are general and can be valued in different perspectives depending in the auditors professionalism and objectivity. The definition of DeAngelo (1981) about the quality of audit stating that: "the quality of audit services is defined to be the market-assessed joint probability that a given auditor will both (a) discover a breach in the client's accounting system, and (b) report the breach" 3 is a very used citation among the quality audit studies. Some authors describe the auditing quality as it is inversely related to reporting failures. That is, a quality auditing is presumed to distinguish more accounting and reporting failures from their clients and vice versa. Some authors simply describe the audit quality as a function of the auditor's ability to detect material misstatements and reporting the errors. ${ }^{4}$ Although there are different definition regarding the auditing quality, in general there are two main factors evolved in the auditing quality definition: the auditor ability in both finding and reporting the misstatements and the auditor independence. These are the two factors that mostly can compose the auditing quality.

\section{Classifications of Factors Affecting the Auditing Quality}

There are is a relatively a wide range of factors that may affect the quality of auditing. As the number of factors affecting the auditing quality is relatively high, there are also various classifications of these factors according to the different authors and entities.Some authors divide in two main groups the factors that can affect the audit quality in direct and indirect measures. Direct factors include factors that are related with the audited company like financial reporting adopted with IAS, quality control reviews, company performance, earning quality etc. Indirect measures contains factors related to the auditing company like audit company size and characteristics', auditor tenure, industry expertise, audit fees, auditors dependence, reputation and the delivering of non-audit services. ${ }^{5}$

IAASB (2011) generalizes the audit quality at the three perspectives: inputs, outputs and external factors. The audit quality can be affected by the resources an audit team input such as auditor skill and experience, ethical values and adopted audit process; audit quality can also be reflected by the production of audit process, which is the auditor's report, or the output; and the third perspective, a strict legal environment may have positive impact in audit quality which are included in external factors.

In this study we will follow the first classifications of direct and indirect measures to classify and analyze in detail these factors.

\subsection{Direct measures}

Although there are various direct factors that can influence the audit quality, the most influence direct factors that can directly affect the audit quality, especially in the Albanian reality are: the earning quality , company performance and client importance.

Earning quality is one of the main elements that can give a presumption regarding the auditing quality. Other authors are convinced that in determining the auditing quality it is sufficient to check the reported earnings of their clients.

${ }^{3}$ DeAngelo, L.E. 1981, "Auditor Size and Audit Quality", Journal of Accounting \& Economics, vol. 3, no. 3

4 Seyyed, A.M., Mahdi, M. and Mohsen, K. 2013, "An Investigation into the Relationship between Audit Committee and Audit Quality", Australian Journal of Basic and Applied Sciences, vol. 6, no. 10

${ }^{5}$ Memis, M.U., and Cetenak, E.H. 2012, "Earnings Management, Audit Quality and Legal Environment: An International Comparison", International Journal of Economics and Financial Issues, vol. 2. 
Generally in developing countries where informality is common the main trend of the management is to avoid as much as it is possible he income taxes. In this situation a company that tends to show their profits as close to the reality, means that its auditor is efficient in performing in a fair and professional way his tasks. The higher the presumptions of a good quality auditing the higher are the reported earnings of the clients financial tables. In same manner, the lower the reported earnings of the clients the lower is presumed to be the auditing quality. Factors that should be taken in consideration to determine the earning quality are: discretionary accruals, meet or beat earnings target, earnings response coefficient, likelihood of reporting a profit etc.

Company performance, is another direct measure that can affect the auditing quality. It is now widely accepted that the internal control has a great influence on the company overall performance. The internal control effectiveness is proportionally related to the company performance. Thus the more efficient the company performance, the greater are the chances that the internal control of that company are efficient. ${ }^{6}$ The more efficient the internal control is, the higher is the expected success rate of the external auditing company, and consecutively the auditing quality.

Client importance is the degree of auditors being economically dependent on the client. That is the economical benefits form a certain client has a relatively important part in the auditor's portfolio. The auditor is dependent on the client to pay the audit fee. The public accounting profession may argue that losing an audit client is nowhere near as serious as losing one's job. Indeed, if an auditor has 100 clients all of equal size, it may not matter much if the auditor loses one of the clients. However, if the auditor only has 2 clients of equal size, it is obvious that the consequences of losing a client will be rather serious to the auditor; in this case it would be hard to argue that the auditor is not biased in favor of the client. ${ }^{7}$

\subsection{Indirect measures}

As mentioned above there are various factors of indirect measures that can affect the audit quality such as auditor characteristics, independence, Level of competition in the audit services market, non-audit services, audit tenure etc.

In auditor characteristics are included several factors such as auditor size, auditor type, skills, expertise etc. Auditor size is a main factor that can affect the auditing quality. Audit firms that are greater in size are considered to be more resistant from management pressures. There exist lot of empirical studies that attempted to find the relationship between audit firm size and auditor's independence. Audit independency has a direct and positive effect on audit quality. The greater the size of the auditing company the greater are the possibilities that this auditing company will try to be as much professional as it can in order to protect its name and reputation by providing higher audit quality. ${ }^{8}$

Auditor skills and expertise in certain sectors, gives the auditors the chance to differentiate themselves from the others, influencing positively their independency and thus the audit quality. The higher the auditors skills and expertise the higher the audit reporting quality is expected to be generated.

Another important factor that can affect the auditing quality is the auditor independence. Auditors' independence is another discussed topic as an important aspect of ethical and a professional issue, crucial to auditors. Auditor independence is a very important in the auditing profession, a crucial element in the statutory corporate reporting process and a key prerequisite for the adding of value to an audited financial statement. There are different definitions of the independent auditor. An independent auditing can be defined as a systematic review of the accuracy and truthfulness of the accounting records of a particular individual, business, or organization by a person or firm skilled in the necessary accounting methods and not related in any way to the person or firm undergoing the audit. Auditor independence is the ability or the state in which the auditor can express it's opinion without being provoked or influenced by external or internal factors. There can be lots of factors that can influence the auditor's opinion in the relation auditor - client relationship such as: auditing fee, non-audit service, intimidation and auditor tenure. Auditor's independency is a crucial element in the auditing profession. If the auditor's independency is not accomplished, then the auditor cannot guarantee the auditing quality.

Audit fee is a primary factor that can be used to percept the auditing quality. In a rational way of thinking, it is presumed that the auditors fees should be proportionally with the auditors work and expertise quality. Thus the higher the

\footnotetext{
${ }^{6}$ Mitra S., Cready W. M., Journal of Accounting, Auditing \& Finance 20 (2005)

7 Whittington, R., \& Pany, K. (2001).Principles of auditing and other assurance servicesÂ (13th ed.).Boston: Irwin/McGraw-Hill

${ }^{8}$ Watkins, A.L., Hillison, W. and Morecroft, S.E. 2004, "Audit Quality: A Synthesis of Theory and Empirical Evidence", Journal of Accounting Literature, vol. 23
} 
auditors fee the higher is the perception of the auditing quality. ${ }^{9}$ Although a higher auditing fee in comparison with other auditors gives a perception of a auditing company with grater staff's expertise, skills some authors think that the auditor's high fee can also be a sign of the extra payment that a company should make to an unqualified report.

Non-audit services are the services that the auditor can make apart from normal auditing procedures, by offering different services to the clients from which he can earn extra revenues. In the last years the demand for business expert services has increased and expended in different range of services which include: training, risk management advice, mergers and acquisition, taxation, portfolio monitoring, recruitment and human resources and corporate governance. An auditor needs to pay much attention when both audit and non-audit services are provided to the same client, because these non-audit services may threaten the independence of auditor. ${ }^{10}$

Intimidation, is the political power and ability to bargain with officials when an auditor examines their quality control methods. Intimidation is proportionally inversely related to the auditing quality. In cases where the intimidation is present the chances for a quality auditing are highly reduced.

Auditor tenure, is the period of time under which the auditor works with a client. Auditor tenure examines whether the length of relationships between auditors and clients could affect negatively on auditor independence. This is a very discussed topic, where some authors think that if there is a long-time cooperation between the auditor and the client the possibility for familiarization is considerably and due to this familiarization the independency of the auditor can be diminished. Other authors think that a long-term cooperation increases the auditors knowledge regarding the audited clients and thus it enhances the chances to distinguish the reporting failures based on familiarity of its business operations and reporting issues.

Level of competition in the audit services market is a crucial element in the quality of the report that the auditors taking part on this market can prepare. Competition is one of the most important environmental factor affecting auditor independence. Firms operating in an intensely competitive environment may have difficulty remaining independent since the client can easily obtain the services of another auditor. A number of empirical studies have proven that the high level of competition in the audit firm has resulted in less auditor independence ${ }^{11}$

\section{The Main Factors Affecting Auditing Quality in Albania}

In Albania the certified public accountant (CPA) can practice the independent auditor based on law no.: $10091 \mathrm{dt}$. 5.03.2009 "For the lawful auditing, organization of the CPA profession and certified accountants". ${ }^{12}$ The organization that regulates and control the auditing quality under this law is IEKA (Institute of certified public accountants), which has proposed a regulation that includes:

- Quality control of auditors

- Quality control in regard of the inner organization of the auditors

The quality control is obligatory and is organized by this institution through an independent committee which is supervised by the board of public surveillance of CPA in Albania. The quality control of the auditors in Albania must be performed, at minimum once in four years for the auditors with experience greater than five years and once in two years for auditors wit experience under five years ${ }^{13}$.

The auditing quality is obligatory and it includes several aspects of auditing firms such as auditing files and reports, auditor's ethics, independency of auditors, the applied auditing fees and other related aspects. Although there is a regulation and an supervising board for auditing quality, still these mechanisms are not enough active and proportionally sufficient in establishing the observance of these rules, including auditor's ethics and quality.

In order to test the factors that are more influential in the auditing companies in Albania, we conducted a questionnaire addressed to the certified public accountants in Albania practicing auditing services. The questionnaire was distributed based on the database of the institute of certified public accountants (IEKA) where there are registered all the

\footnotetext{
${ }^{9}$ Skinner, D.J. and Srinivasan, S. 2012, "Audit Quality and Auditor Reputation: Evidence from Japan", The Accounting Review, vol.87, no. 5

10 Salehi, M. (2008), "Corporate Governance and Audit Independence: Empirical Evidence of Iranian Bankers," International Journal of Business and Management, Vol. 3, No. 12,

11 Myers, J. N., L. A. Myers, and T. C. Omer. 2003. Exploring the term of the auditor-client relationship and the quality of earnings: $A$ case for mandatory auditor rotation? The Accounting Review 78 July.

${ }^{12} \mathrm{http}: / / \mathrm{kkk}$.gov.al/faqe.php?id=3\&/2=118

${ }^{13}$ http://www.ieka.al/
} 
CPA in Albania. The questionnaire contained general information about the auditor, and the auditors were asked to evaluate at their opinion how a given factor affect the auditing quality in Albania, by evaluation in a scale from 1 to, where 1 is no effect on auditing quality and 5 extremely high effect on auditing quality. The response rate was low and only 12\% of the questionnaires were completed.

\section{Main Findings and Conclusions}

From the section of direct measurements, according to the respondents the factors that mostly influence the Albanian auditor's quality was the earning quality. From the returned questionnaires $47 \%$ of the respondent thinks that the reported earning quality of the audited company generally are slightly over the allowed fiscal limitations. In this perspective the earnings reported from the audited firms are perceived to be formal rather than the real earning power, from the Albanian auditors. In this situation the low, reported earnings of the audited companies have a direct, negative perception on the auditing quality of auditors, auditing these companies. From the returned questionnaires $27 \%$ of the respondent think that the client importance has a vital role in the auditing quality. The companies that have a relatively important part in the auditor's portfolio are treated in an asymmetrically way compared with companies with low incomes form the auditors portfolio perspective.

From the indirect measures the factors that mostly influence the Albanian auditors quality were the auditors independency rated by $34 \%$ of the respondents. As observed form the responses the auditors independency in Albania is still an issues that needs further attention. The auditors independency in Albania is in low levels, from the perception of the Albanian auditors, where elements of auditor's ethics are not in the desired levels. $27 \%$ of the respondent rated auditor tenure as another main factor that influences the auditing quality Concretely auditor's tenure is long-term , and affecting considerably the familiarity with the clients. This connection affects directly and negatively the auditors independency, resulting in a low quality performance.16\% of the respondent, listed auditors characteristics as main factor in affecting the auditing quality, where issues such as auditors skills and expertise were the more concerned issues affecting negatively in Albanian auditor's independence. Non-auditing services are still new products for the Albanian market, and only $6 \%$ of the respondents claimed that this factor affects negatively the auditing quality in Albania. From the returned questionnaires $17 \%$ of the respondents listed other factors affecting the auditing quality in Albania, rather from those specified in this study.

Throughout this study we tried to list and make a classification of the main factors affecting the auditing quality in Albania. Although the listed factors, we are conscious that there are still many different factors and audit quality issues happening not only in Albania, but worldwide. As this issue concerns there is still lot of progress to be made in a better understanding of the importance of the audit quality and the factors that affect it.

We encourage the national regulators and institutions instead of just adopting the international standards, to also, monitor the process of the implementation of this standards in order to increase the audit quality in Albania. We are conscious, that it is impossible to totally eliminate the audit quality issues as the audit quality is a dynamic concept, where the factors that contribute and affect the audit quality can change over time due to and politic and market indicators and overall perception. In this perspective only by evaluating the role of each factor in auditing quality can minimize the risks of auditing quality.

\section{References}

Sridhar Ramamoorti (2003), internal auditing: history, evolution, and prospects. IIARF publishing.

DeAngelo, L.E. 1981, "Auditor Size and Audit Quality", Journal of Accounting \& Economics, vol. 3, no. 3

Seyyed, A.M., Mahdi, M. and Mohsen, K. 2013, "An Investigation into the Relationship between Audit Committee and Audit Quality", Australian Journal of Basic and Applied Sciences, vol. 6, no. 10

Memis, M.U., and Cetenak, E.H. 2012, "Earnings Management, Audit Quality and Legal Environment: An International Comparison", International Journal of Economics and Financial Issues, vol. 2.

Mitra S., Cready W. M., Journal of Accounting, Auditing \& Finance 20 (2005)

Whittington, R., \& Pany, K. (2001).Principles of auditing and other assurance servicesÂ (13th ed.).Boston: Irwin/McGraw-Hill

Watkins, A.L., Hillison, W. and Morecroft, S.E. 2004, "Audit Quality: A Synthesis of Theory and Empirical Evidence", Journal of Accounting Literature, vol. 23

Skinner, D.J. and Srinivasan, S. 2012, "Audit Quality and Auditor Reputation: Evidence from Japan", The Accounting Review, vol.87, no. 5

Salehi, M. (2008), "Corporate Governance and Audit Independence: Empirical Evidence of Iranian Bankers," International Journal of Business and Management, Vol. 3, No. 12, 
Myers, J. N., L. A. Myers, and T. C. Omer. 2003. Exploring the term of the auditor-client relationship and the quality of earnings: A case for mandatory auditor rotation? The Accounting Review 78 July.

http://www.grfcpa.com/media/AuditorDoesandDoesntDo_Final.pdf

http://www.ieka.al/

http://kkk.gov.al/faqe.php?id=3\&/2=118 